\title{
Isolation and characterisation of Heterorhabditis spp. (Nematoda: Heterorhabditidae) from Hungary, Estonia and Denmark
}

\author{
Christine T. Griffin, Ilona Dix, Susan A. Joyce, Ann M. Burnell and Martin J. Downes \\ Department of Biology, National University of Ireland, Maynooth, Co. Kildare, Ireland
}

Accepted for publication:31 May 1998

\begin{abstract}
Summary - Targeted surveys were conducted for the entomopathogenic nematode Heterorhabditis in areas of Denmark, Estonia and Hungary. Isolates were identified by IEF, PCR and cross-fertility tests as belonging to three distinct taxonomic groups: H. bacteriophora, the north-west European (NWE) type of H. megidis and the Irish type of Heterorhabditis. The Irish and NWE types of Heterorhabditis were both present in Denmark (at six and four sites, respectively), while only the NWE type was recovered in Estonia. H. bacteriophora was the dominant heterorhabditididentified in Hungary (ten sites), but the Irish type was also detected at two sites. This is the first report of the Irish type of Heterorhabditis on continental Europe. Co-occurrence of two Heterorhabditis types at a single site was noted in Denmark (Irish and NWE) and in Hungary (Irish and H. bacteriophora). Heterorhabditis was recovered at $38.5 \%$ of sites $(\mathrm{n}=26)$ in Denmark (north coast of Sjælland), 27.3\% of the coastal sites $(n=22)$ in Estonia, and 32.6\% of sites $(n=46)$ in Hungary.
\end{abstract}

Résumé - Isolation et caractérisation d'espèces d'Heterorhabditis (Nematoda: Heterorhabditidae) originaires de Hongrie, d'Estonie et du Danemark - Des prospections ciblées ont été effectuées dans certaines régions du Danemark, d'Estonie et de Hongrie pour rechercher les nématodes du genre Heterorhabditis. Les souches, identifiées par les méthodes de concentration isoélectrique, de PCR et d'hybridation, appartiennent aux trois groupes taxinomiques d'Heterorhabditis. H. bacteriophora, le groupe de l'Europe du nord-ouest (NWE) de H. megidis et le groupe irlandais d'Heterorhabditis. Le groupe irlandais et le groupe NWE sont tous les deux présents au Danemark (dans six et quatre sites, respectivement), mais seul le dernier groupe a été rencontré en Estonie. H. bacteriophora, présent dans dix sites, est l'espèce dominante d' Heterorhabditis en Hongrie, mais le groupe irlandais a été également détecté dans deux sites. C'est la première fois que le groupe irlandais est rencontré en Europe continentale. La présence simultanée de deux types d' Heterorhabditis est signalée au Danemark (groupe irlandais et groupe NWE) et en Hongrie (groupe irlandais et H. bacteriophora). Des Heterorhabditis ont été collectés sur 38.5\% des 26 sites du Danemark (côte nord de Sjælland), 27.3\% des 22 sites du littoral estonien et $32.6 \%$ des 46 sites de Hongrie.

Keywords: biological control, entomopathogenic nematode, geographic distribution, identification, soil survey.

Entomopathogenic nematodes of the families Heterorhabditidae and Steinernematidae have considerable potential for the control of insect pests. The non-feeding infective juvenile (IJ) can survive in the soil for several months until susceptible insects are encountered. The IJs enter insects and, together with their symbiotic bacteria, kill them within days.

Surveys for entomopathogenic nematodes have been conducted in many parts of the world, including Australia (Akhurst \& Bedding, 1986), the United States (Akhurst \& Brooks, 1984; Hara et al., 1991) and Europe (Mrácek, 1980; Deseö \& Miller, 1985; Burman et al., 1986; Blackshaw, 1988; Vänninen et al., 1989; Hominick \& Briscoe, 1990; Griffin et al., 1991; 1994b), for the purposes both of recovering potentially useful isolates and of gaining an insight into the ecology of the nematodes.

Smits et al. (1991) identified Heterorhabditis isolates from Europe, on the basis of restriction length polymor- phisms, as being of three types: Heterorhabditis bacteriophora, the north-west European (NWE) group and the Irish group. Current evidence suggests that the H. bacteriophora group is the dominant Heterorhabditis in southern and central Europe. Thus, Smits et al. (1991) identified isolates from Italy, Spain, central Germany (Darmstadt), and Moldova as $H$. bacteriophora, and the species has also been isolated in the south of France (Grenier et al., 1996). Mrácek and Jenser (1988) identified a heterorhabditid isolated near Budapest as $H$. heliothidis, which is now considered to be conspecific with $\mathrm{H}$. bacteriophora (Poinar, 1990). Isolates from the Netherlands, Poland and the north of Germany were assigned by Smits et al. (1991) to the NWE type of Heterorhabditis. This type has also been isolated in the south of England (Hominick et al., 1995) and in Belgium (Miduturi et al., 1996). While most of the records of it have been from northern Europe, the type was also recovered in north- 
ern Greece (Menti et al., 1997). The Irish type of Heterorhabditis is, to date, the only heterorhabditid to have been isolated in Ireland, where it is relatively common in sandy coastal grasslands (Griffin et al., 1994a). It was also found associated with coastal sites in Britain (Griffin et al., 1994b; Hominick et al., 1995), but has not previously been recorded outside of these islands.

The NWE type of Heterorhabditis and H. megidis share the same rDNA restriction profiles for all the restriction enzymes tested by Joyce et al. (1994a). There is strong evidence, however, that the Irish type represents a separate species. Irish type isolates possess a distinctive IEF protein electrophoregram (Joyce et al., 1994b) and a distinctive repetitive DNA restriction profile (Smits et al., 1991). Also, they can be distinguished from NWE type Heterorhabditis by mtDNA and rDNA ITS restriction profiles for selected enzymes (Joyce et al., 1994a), and they are reproductively isolated from $H$. megidis and NWE isolates (Dix et al., 1992; Griffin et al., 1994b; Joyce et al., 1994b). Adams et al. (1998) sequenced 716 bases of the rDNA ITS1 region of nine putative species of Heterorhabditis and observed 35 nucleotide substitutions between the Irish type isolate K122 and H. megidis, two of which are autapomorphies for K122. There is thus cumulative evidence that $H$. megidis and NWE type are conspecific but the Irish type is a distinct species.

Here we report the results of a sampling programme in Hungary, Denmark and Estonia. There are no previous reports of entomopathogenic nematodes from Denmark or Estonia. In Hungary, limited sampling in the vicinity of Budapest recovered a single H. bacteriophora isolate (Mrácek \& Jenser, 1988). The present sampling programme was part of a broader search in Europe aimed at the recovery of novel wild type strains of Heterorhabditis with useful traits. Therefore, sampling was directed at sites at which it was considered likely that the genus was present, viz sandy soils, and especially coastal sites, which we (Griffin et al., 1994b) and others (e.g. Hara et al., 1991; Amarasinghe et al., 1994) have found to be a suitable habitat for heterorhabditids.

\section{Materials and methods}

\section{SURVEY AND SAMPLING}

Potential sampling sites in Denmark, Estonia and Hungary were initially identified from maps and geological data and subsequently by local inspection. Sites in Denmark and Estonia were all coastal (Fig. 1A, B). In
Denmark, sampling was restricted to the north coast of Sjælland (Fig. 1A). Sampling in Hungary was conducted in two regions where soils are relatively sandy, near Kecskemét and Debrecen, respectively (Fig. 1C, D). Between the rivers Danube and Tisza, in and around the Kiskungsági National Park (south of Kecskemét; BácsKiskun county), there are extensive sand hills consisting of river deposited sand reworked by the wind. The second area in Hungary was to the north and east of Debrecen (Hajdú-Bihar and Szabolcs-Szatmár counties).

Soil sampling and baiting with Galleria mellonella were as described by Griffin et al. (1994b) with the addition that samples found to be positive for Heterorhabditis were baited a second time. The main sampling programme was conducted in October-November, 1991. Targeted sampling to confirm some of the original findings was carried out in Sjælland in December, 1992 and in Hungary in June, 1994.

\section{MOLECULAR CHARACTERISATION}

The isolates from the main sampling programme were identified from protein isoelectric focusing electrophoregrams ( $\mathrm{pH}$ range 3-10) of soluble proteins from IJ as described by Joyce et al. (1994b). This diagnosis was subsequently confirmed by restriction enzyme digest of the internal transcribed spacer (ITS) region of rDNA as described by Joyce et al. (1994a), using the MboI restriction enzyme. Isolates from later targeted sampling programmes were characterised using rDNA ITS restriction profiles only.

In the case of isolates expressing the HP88 restriction profile, the rDNA non transcribed spacer (NTS) region was amplified as described by Joyce et al. (1994c) and the ca $1.4 \mathrm{~kb}$ amplification product DNA was digested using the enzymes HaeIII and HpaII.

\section{CROSS-BREEDING STUDIES}

Interstrain crosses were performed on lipid agar plates as described by Dix et al. (1992). At least 60 second generation virgin females were used for each interstrain cross. Reference strains used for the identification of newly isolated nematodes are shown in Table 1.

\section{Results}

Heterorhabditis was isolated in Sjælland (Denmark), Estonia and Hungary. There was no difference between 


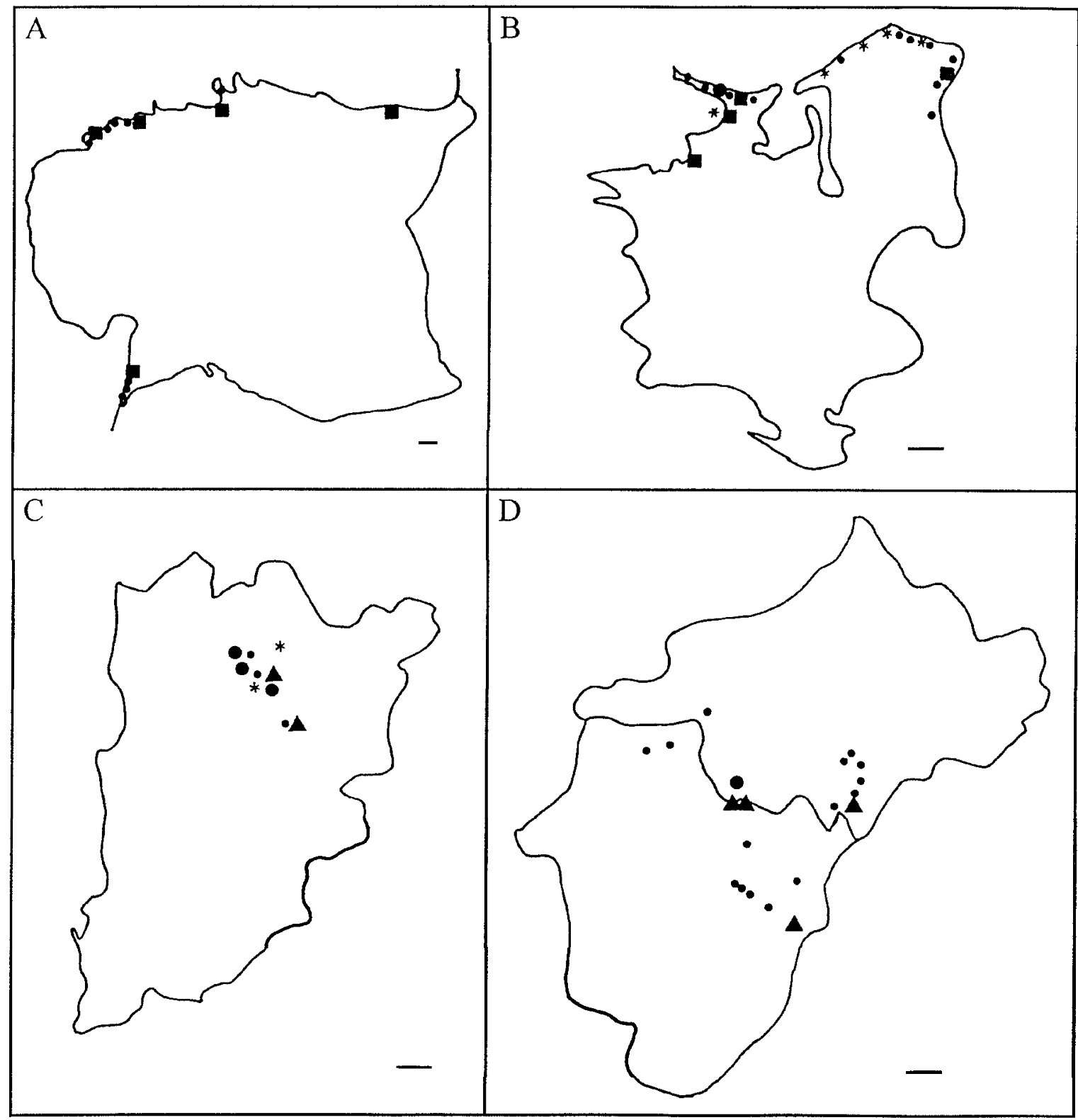

- NWE type Heterorhabditis

- H. bacteriophora
* Irish type Heterorhabditis

- unidentified Heterorhabditis

- $\quad$ site where Heterorhabditis was not found

Fig. 1. Sites sampled for Heterorhabditis A: Estonia; B: Sjaelland, Denmark; C: Kecskemét region (Bács-Kiskun county), Hungary and D: Debrecen region (Hajdú-Bihar and Szabolcs-Szatmár counties), Hungary. (Each symbol may represent more than one site; scale bar $=10 \mathrm{~km})$. 
Table 1. Origin and source of reference strains of Heterorhabditis

\begin{tabular}{llll}
\hline Name & Origin & ITS restriction profile \\
\hline HB1 & Brecon, Australia & H. bacteriophora & Source \\
HP88 & Utah, USA & H. bacteriophora HP88 & R.J. Akhurst $^{*}$ \\
Darmstadt & Darmstadt, Germany & H. bacteriophora HP88 & P. Westerman \\
K122 & Wexford, Ireland & Irish type & Own collections \\
HF85 & Flevopolder, The Netherlands & H. megidis NWE type & P. Westerman \\
\hline
\end{tabular}

* CSIRO, Canberra, Australia.

** Van Hall Institute, Leeuwarden, The Netherlands.

*** New Zealand Pastoral Agriculture Research Institute Ltd., Lincoln, New Zealand.

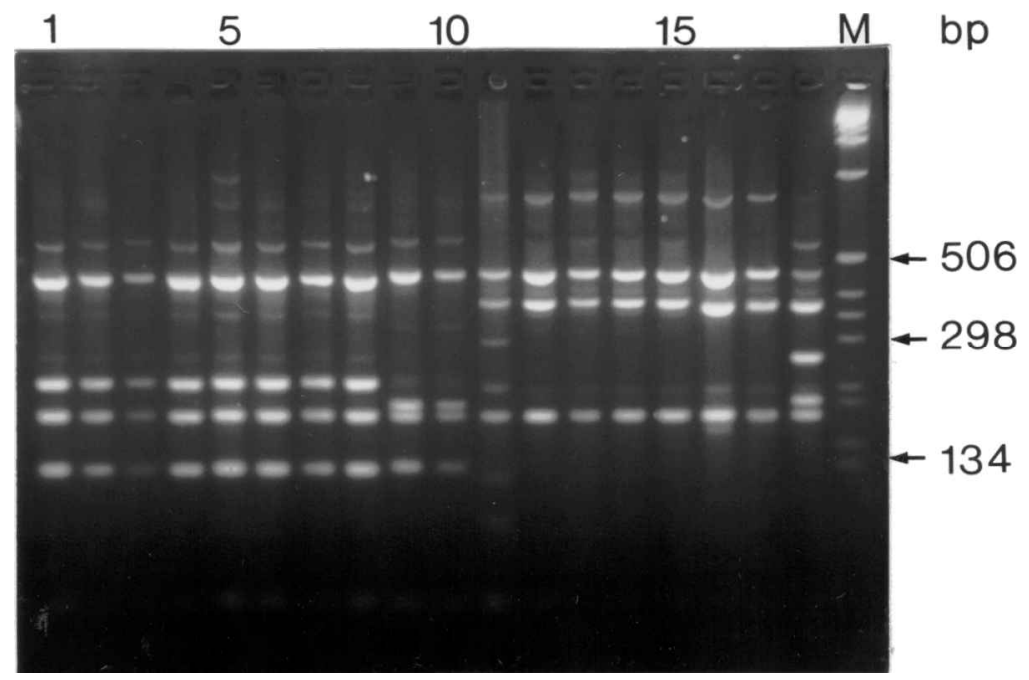

Fig. 2. MboI restriction digests of the PCR amplification products of the rDNA internal transcribed spacer region of Heterorhabditis isolates, separated on a 2\% agarose gel. 1: EU333; 2: EU335; 3: EU347; 4: EU348; 5: EU349; 6: EU94; 7: EU106; 8: K122; 9: EU85; 10: HF85; 11: EU339; 12: EU362; 13: EU367; 14: EU368; 15: EU369; 16: HP88; 17: Darmstadt; 18: HB1; M: 1 kb marker. Strains EU85 (lane 9) and EU106 (lane 7) are from Denmark, all other strains with the EU designation are from Hungary.

the three countries in the proportion either of sites or of samples positive for Heterorhabditis (Table 2). Overall, the genus was recovered at $33 \%$ of sites, and in $16 \%$ of samples. Three species were detected (Table 2): H. megidis NWE type in Denmark and Estonia; Irish type Heterorhabditis in Denmark and Hungary, and H. bacteriophora (HP88 type restriction profile) in Hungary. The $M b o I$ restriction profiles of the rDNA ITS region from a representative sample of these isolates are shown in Fig. 2. The faint bands visible on this gel represent incomplete digestion products.

\section{SJÆLLAND (DENMARK) AND ESTONIA}

All of the sites sampled in Sjælland and Estonia (and hence all of the sites positive for Heterorhabditis) were within $1.5 \mathrm{~km}$ of the sea; the majority were within $200 \mathrm{~m}$ of it. In Estonia, Heterorhabditis was detected at six of the 22 sites sampled, and all isolates were identified as the NWE type (Table 2; Fig. 1A). Positive sites included meadow, recreational grassland areas, open coniferous forest with extensive grass cover and the margins of a cereal field (Table 3).

Both the Irish type and NWE type of Heterorhabditis were isolated in Sjælland (Table 2; Fig. 1B). Most of the sites from which Heterorhabditis was recovered were dune or turf recreational areas, often with shrubs and/or conifers present (Table 3). Both Irish and NWE types occurred together at one site, Gudmindrup Lyng. Six samples were taken at this site; the NWE and Irish types were each recovered from one sample. The Irish type 
Table 2. Occurrence of three types of Heterorhabditis (H. bacteriophora [H.b] Group, the North West European type of H. megidis [H.m] and Irish type Heterorhabditis) at sites in Hungary, Denmark and Estonia, October-November 1991.

\begin{tabular}{|c|c|c|c|c|c|c|}
\hline \multirow[t]{2}{*}{ Country } & \multirow{2}{*}{$\begin{array}{l}\text { Number of } \\
\text { sites and } \\
\text { samples }\end{array}$} & \multirow{2}{*}{$\begin{array}{l}\text { Number (\&\%) } \\
\text { of sites and } \\
\text { samples with } \\
\text { Heterorhabditis }\end{array}$} & \multicolumn{4}{|c|}{$\begin{array}{l}\text { Number of sites with Heterorhabditis } \\
\text { identified to species }\end{array}$} \\
\hline & & & Total & H.b & H.m & Irish \\
\hline Estonia & $\begin{array}{l}22 \\
\mathbf{8 1}\end{array}$ & $\begin{array}{l}6(27.3 \%) a \\
\mathbf{9}(\mathbf{1 1 . 1 \% ) a} a\end{array}$ & 6 & 0 & 6 & 0 \\
\hline $\begin{array}{l}\text { Sjælland } \\
\text { (Denmark) }\end{array}$ & $\begin{array}{l}26 \\
85\end{array}$ & $\begin{array}{l}10(38.5 \%) a \\
15(17.6 \%) a\end{array}$ & 9 & 0 & 4 & 6 \\
\hline $\begin{array}{l}\text { Hungary } \\
\text { Kecskemét }\end{array}$ & $\begin{array}{l}22 \\
39\end{array}$ & $\begin{array}{l}10(45.5 \%) A \\
\mathbf{1 2}(\mathbf{3 0 . 8 \% ) A}\end{array}$ & 8 & 6 & 0 & 2 \\
\hline Debrecen & $\begin{array}{l}24 \\
\mathbf{5 7}\end{array}$ & $\begin{array}{l}5(20.8 \%) A \\
6(\mathbf{1 0 . 5 \% ) B}\end{array}$ & 4 & 4 & 0 & 0 \\
\hline Total & $\begin{array}{l}46 \\
96\end{array}$ & $\begin{array}{r}15(32.6 \%) a \\
\mathbf{1 8}(\mathbf{1 8 . 8 \% )} \boldsymbol{a}\end{array}$ & 12 & 10 & 0 & 2 \\
\hline
\end{tabular}

Entries followed by the same letter do not differ significantly $(P \leqslant 0.05)$ from each other. Lower case letters: between countries (chi-square test); upper case letters: between regions of Hungary (Fisher's exact test). Normal letters: sites; bold letters: samples.

was recovered from the landward side of a dune ridge, with mainly shrubs (Rosa rugosa, Empetrum nigrum and heathers) and some grass, while the NWE type came from a grass/clover roadside verge bordering that area. An examination of the site descriptions for other $\mathrm{He}$ terorhabditis-positive sites in Sjælland suggested a possible association between the presence of Irish Heterorhabditis and Rosa rugosa. Excluding Gudmindrup Lyng, where both nematode types occurred, roses were present at four of the five Irish-positive sites, but at none of the three NWE-positive sites. A test of association between nematode type and presence of roses at nematodepositive sites was significant at $P=0.07$ (Fisher's exact test).

\section{HUNGARY}

$H$. bacteriophora was the dominant type present in Hungary, but the Irish type was identified at two sites in the Kecskemét region (Table 3; Fig. 1C). Heterorhabditispositive sites in Kecskemét included meadow, pasture, a grassy hillside with juniper, a rye field with associated verge, a wooded roadside verge, and the bank of a driedup alkaline lake (Table 3). In the Debrecen area, only H. bacteriophora was detected (Fig. 1D). Sites in this region had the heaviest soils of all those sampled in any of the three countries, being sandy loams or sandy clay loams rather than sands. Positive sites here were pasture, waste grassland and the margins of a maize field (Table 2).

Overall, one third of the sites sampled in Hungary were positive for Heterorhabditis (Table 2). Heterorhabditis was detected at a higher proportion of sites in the Kecskemét region (46\%) than in the Debrecen region $(21 \%)$, and the difference was significant at $P=0.054$ (Fisher's exact test). The difference between these two regions of Hungary reached significance at $P \leqslant 0.05$ when the proportion of positive samples was compared (31 vs $11 \%$ ) (Table 2). When only the data for H. bacteriophora (which occurred in both regions) were considered, the prevalence remained higher in Kecskemét (6/22 sites, 6/39 samples) than Debrecen (4/24 sites, 4/59 samples) but the difference was not significant for either sites or samples.

In a restricted sampling programme in June 1994, several soil samples were taken at each of the two Kecskemét sites at which the Irish type Heterorhabditis isolates (EU167 and EU176) had been recovered in 1991. These were respectively, a wide roadside verge with hedgerow broadening to deciduous woodland, and a low-lying pasture with reeds (Phragmites australis) adjoining the sampled area. Irish type Heterorhabditis was again isolated in 
Table 3. Locations of sites where Heterorhabditis was detected in October-November 1991, the habitat from which positive samples were taken, and the identity of the isolated Heterorhabditis (H.m.: H. megidis NWE type; H.b.: H. bacteriophora: Irish: Irish type of Heterorhabditis; Het.: identified to genus only).

\begin{tabular}{|c|c|c|c|}
\hline Site location & $\begin{array}{l}\text { Sample/isolate } \\
\text { code }\end{array}$ & $\begin{array}{l}\text { Identity } \\
\text { of isolate }\end{array}$ & Habitat at sample \\
\hline \multicolumn{4}{|l|}{ Estonia } \\
\hline Tallinn & EU6 & H.m. & Park: turf with Elymus \\
\hline Keile Joa & EU17 & H.m. & Open conif. forest with grass cover \\
\hline Lohusalu & EU21 & H.m. & Meadow \\
\hline \multirow[t]{2}{*}{ Taagupi } & EU36 & H.m. & Grass \\
\hline & EU38 & H.m. & Weedy margin of cereal field \\
\hline \multirow[t]{2}{*}{ Aa } & EU70 & H.m. & Turf grass \\
\hline & EU71 & H.m. & Grassy slope \\
\hline \multirow[t]{2}{*}{ Tsitre } & EU80 & & Meadow \\
\hline & EU81 & Het. & Meadow \\
\hline \multicolumn{4}{|l|}{ Denmark: Sjælland } \\
\hline Mørdrup & EU85 & H.m. & Grass (waste ground) \\
\hline Hornbæk & EU94 & Irish & $\begin{array}{l}\text { Open coniferous forest with ground oak, } \\
\text { roses and grass }\end{array}$ \\
\hline \multirow[t]{2}{*}{ Gilleleje } & EU103 & Het. & Grassy slope \\
\hline & EU106 & **Irish & Shrubs and long grass \\
\hline Rågeleje & EU114 & Irish & Meadow \\
\hline \multirow{2}{*}{ W. of Rågeleje } & EU116 & Irish & Grass \\
\hline & EU121 & Irish & Grassy slope \\
\hline \multirow[t]{2}{*}{ Liseleje } & EU132 & Irish & Dunes, some roses \\
\hline & EU133 & Het. & Dunes, some roses \\
\hline \multirow[t]{2}{*}{ Nyrup } & EU140 & H.m. & Long grass, scattered conifers \\
\hline & EU141 & Het. & Long grass, scattered conifers \\
\hline Lumsas & EU143 & Het. & Grass (parking place) \\
\hline \multirow[t]{2}{*}{ Gudmindrup Lyng } & EU158 & Irish & Grass/rose/heather/Vaccinium \\
\hline & EU162 & H.m. & Grass verge \\
\hline Vindekilde & EU166 & H.m. & Old dunes, long grass \\
\hline \multicolumn{4}{|l|}{ Hungary: Kecskemét } \\
\hline \multirow[t]{2}{*}{ Near Kecskemét } & EU167 & $* *$ & Roadside verge with trees \\
\hline & & $* * *$ Irish & \\
\hline *KNP IV & EU173 & *** Het. & Short grass, bank of dry alkaline lake \\
\hline near KNP V & EU175 & Het. & Pasture \\
\hline KNP V(1) & EU176 & *** Irish & Pasture \\
\hline KNP V(2) & EU178 & H.b. & Rye field including verge \\
\hline KNP V(3) & EU185 & H.b. & Sand hills; grass and juniper \\
\hline \multirow[t]{2}{*}{ KNP V(4) } & EU188 & H.b. & Meadow on hillside \\
\hline & EU190 & Het. & Pasture \\
\hline KNP V(5) & EU193 & H.b. & Meadow \\
\hline \multirow[t]{2}{*}{ KNP V(6) } & EU195 & H.b. & Meadow \\
\hline & EU196 & Het. & Meadow \\
\hline KNP VI (Bugac) & EU201 & H.b. & Cut pasture \\
\hline
\end{tabular}


Table 3. (Continued).

\begin{tabular}{llll}
\hline Site location & $\begin{array}{l}\text { Sample/isolate } \\
\text { code }\end{array}$ & $\begin{array}{l}\text { Identity } \\
\text { of isolate }\end{array}$ & Habitat at sample \\
\hline $\begin{array}{l}\text { Hungary: Debrecen } \\
\text { Létavértes }\end{array}$ & EU222 & H.b. & Sheep pasture \\
Nyírbéltek & EU228 & H.b. & Pasture on hill \\
Téglás & EU229 & Het. & Pasture \\
Téglás-Újfehértó & EU246 & H.b. & Grass with shrubs (waste ground) \\
Újfehértó & EU249 & H.b. & Margins of maize field \\
\hline
\end{tabular}

* KNP IV-VI: Kiskunsagi National Park, Regions IV-VI.

** Irish type re-isolated in Nov. 1992 (Sjælland) or June 1994 (Kecskemét: EU333, EU335, EU347, EU348 and EU349).

*** Hb. Re-isolated in June 1994 (EU339 near Kecskemét; EU369 at KNP IV; EU362 \& EU367 at KNP V(1)).

the verge (site of EU167), where it was detected in 5/20 samples, but it was not isolated in any of seventeen samples from the pasture (site of EU176). This time, H. bacteriophora was present at both sites (verge: $1 / 20$ samples; pasture: $2 / 17$ samples), though it had not been detected at either site in the 1991 sampling programme.

The average number of bait insects parasitised (luminescent) in the Heterorhabditis-positive samples from Kecskemét was similar to that for Denmark and Estonia, while significantly more insects were parasitised in the Debrecen samples (Fig. 3). To test whether the different parasitisation levels in the Debrecen and Kecskemét samples was due to differences in species composition between the two areas, a comparison was made testing only those samples in which $H$. bacteriophora was identified. $H$. bacteriophora-positive samples from Kecskemét yielded less than half as many parasitised cadavers per sample as the $H$. bacteriophora-positive Debrecen samples (Kecskemét: $\mathrm{x}=2.3 \pm 0.76, \mathrm{n}=6$; Debrecen: $\mathrm{x}=6.0 \pm 2.04, \mathrm{n}=4$ ) and the difference was significant at $P=0.086$ (Student's t test).

\section{CROSS-BREEDING STUDIES}

Hungarian and Danish isolates which display an Irish type profile are interfertile with each other and with the Irish type isolate K122, from Ireland (Table 4). When the females of the Irish type isolate EU114 (Denmark) were crossed with males of the NWE type isolate EU85 (also from Denmark), embryonic lethal progeny resulted (not in table). Crosses between Hungarian isolates with the Irish type profile and Hungarian isolates with the HP88-type profile gave rise to embryonic lethal progeny (data not shown).

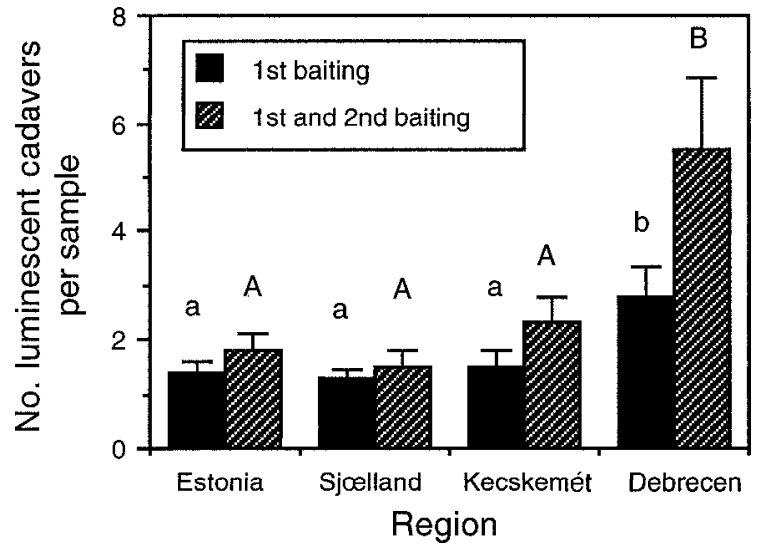

Fig. 3. Mean number of luminescent Galleria mellonella cadavers per Heterorhabditis-positive soil sample from Estonia, Denmark (Sjeelland), and Hungary (Kecskemét and Debrecen). Data are for first baiting and total (first and second) baiting. Bars accompanied by the same letter are not significantly different $(P \leqslant 0.05$, Duncan's multiple range test); lower case letters: first baiting; upper case letters: total baiting.

Hungarian isolates having the same ITS region $\mathrm{MboI}$ restriction profile as the $H$. bacteriophora HP88 strain were not interfertile when crossed with it. The cross of HP88 females and Hungarian HP88 type males (EU362 and EU369) gave sterile F1 progeny while the reciprocal cross resulted in embryonic lethals. Crosses set up with Darmstadt (a European isolate with the HP88 type profile and interfertile with HP88) gave the same results with these isolates as did the cross with HP88 itself (Table 5). None of the restriction enzymes used to digest either the ITS region or the NTS region of the rDNA gene complex revealed a difference between the Hungarian HP88 type 
Table 4. Crosses between Heterorhabditis isolates sharing the "Irish type" rDNA ITS restriction profile and resulting in fertile progeny $(+)$.

\begin{tabular}{lllll}
\hline Female & \multicolumn{3}{c}{ Male } \\
\cline { 2 - 5 } & $\begin{array}{l}\text { K122 } \\
\text { (Ireland) }\end{array}$ & $\begin{array}{l}\text { EU94 } \\
\text { (Denmark) }\end{array}$ & $\begin{array}{l}\text { EU106 } \\
\text { (Denmark) }\end{array}$ & $\begin{array}{l}\text { EU333 } \\
\text { (Hungary) }\end{array}$ \\
\hline K122 & + & + & + & $+\begin{array}{l}\text { EU349 } \\
\text { (Hungary) }\end{array}$ \\
EU94 & + & + & + & + \\
EU349 & + & + & + & + \\
\hline
\end{tabular}

Table 5. Crosses between isolates sharing the H. bacteriophora HP88 type rDNA ITS restriction profile.

\begin{tabular}{lllll}
\hline Female & & & Male & \\
\cline { 2 - 5 } & HP88 & Darmstadt & EU362 \\
(USA) & (Hungary) & EU369 \\
(Hungary)
\end{tabular}

$+:$ cross resulted in fertile progeny.

e.l.: embryonic lethal.

F1: sterile F1 adults.

n.d.: not determined.

isolates and HP88 itself. Fig. 4 shows a HaeIII digestion profile of the rDNA NTS region of five Hungarian $\mathrm{H}$. bacteriophora HP88 type isolates. All of these isolates share the same NTS restriction profile as the HP88 isolate, having four restriction fragments of $c a 620,332,197$ and 148 bp. The faint bands visible on this gel most probably represent incomplete digestion products.

\section{Discussion}

Isoelectric focusing electrophoregrams of soluble proteins from IJ and the pattern of the restriction enzyme digest of the ITS region of rDNA revealed that both NWE type $H$. megidis and Irish type Heterorhabditis occur in Denmark. Isolates showing the Irish type PCR profile were also recovered from soil samples collected in the Kecskemét region of Hungary. The cross-breeding studies showed that these Hungarian and Danish Irish type isolates are interfertile with each other and with the Irish type isolate K122 (from Ireland). This indicates that the Irish type of Heterorhabditis is not restricted to the coastal region of Ireland and Britain (Griffin et al., 1994b; Hominick et al., 1995), but occurs in central and northern Europe as well.

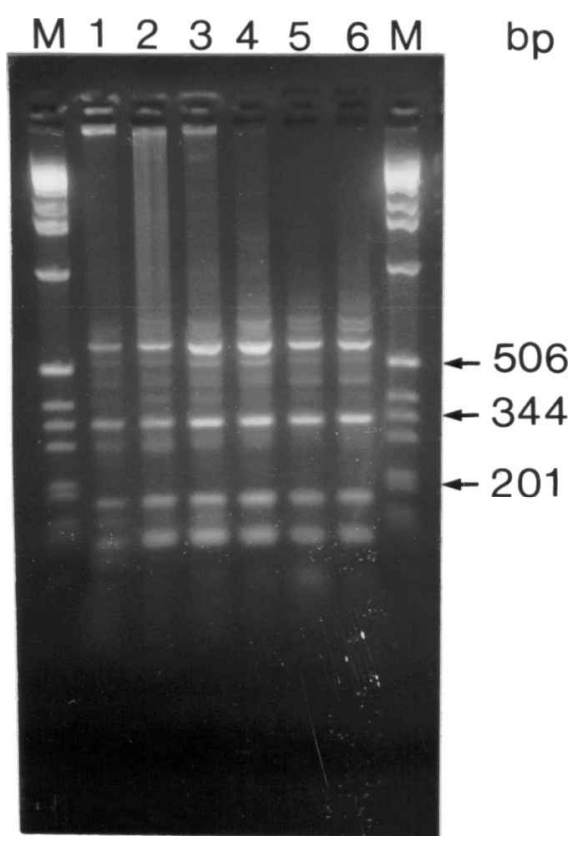

Fig. 4. HaeIII restriction digests of the PCR amplification products of the rDNA non-transcibed spacer region of Hungarian isolates of the HP88 (H. bacteriophora) type separated on a 2\% agarose gel. 1: HP88; 2: EU339; 3: EU362; 4: EU367; 5: EU368; 6: EU369; M: 1 kb DNA ladder (Gibco BRL). 
NWE type $H$. megidis predominates on the northern continental fringe, being the only Heterorhabditis isolated to date from the Netherlands (Hominick et al., 1995), Belgium (Miduturi et al., 1996), northern Germany and Poland (Smits et al., 1991) and Estonia (present study). The NWE type has also been identified from the south east of England (Hominick et al., 1995) where the climate of Britain most resembles that of the continental fringe. In contrast, the Irish type Heterorhabditis is the only one recovered in Ireland and in all but the south east of Great Britain. This might suggest that it is a species of mild, wet climates. However, its discovery at central European sites in Hungary and on a portion of the continental fringe in Denmark, where it occurs with the NWE type, suggests that the picture is more complicated: further sampling effort will clearly be necessary to delineate its distribution range. The apparent absence of the Irish type in Estonia, with its relatively long cold winters, would support the thesis that the Irish type is a species of equitable climates.

Moreover, bearing in mind that soils sampled were of a similar, sandy texture, it is striking that Irish type $\mathrm{He}$ terorhabditis occurred at a lower prevalence toward the climatically more extreme centre of the continent (Hungary, $4 \%$ of sites) than in Denmark (23\% of sites) or in Ireland and Britain, where it was detected at an average of $12 \%$ of sites (Griffin et al., 1994b). This suggests that it is less successful in the conditions prevailing in Hungary, which would accord with the poorer heat tolerance of Irish type isolates than of Hungarian $H$. bacteriophora reported by Finnegan et al. (1999). The site at which the Irish type was detected in both of the Hungarian samplings (November, 1991 and June, 1994) was a roadside verge shaded by trees — virtually a small woodland; few other wooded sites were included in this study. In the Negev region of Israel, Heterorhabditis densities were higher in plots with a high degree of shade (Glazer et al., 1996). Perhaps in Hungary, Irish type Heterorhabditis is favoured by woodland, where lower temperatures and higher soil moisture would be expected than in the neighbouring grassland. While the other Hungarian site at which the Irish type was recovered was open grassland, it was bordered by reeds, indicating a high water table. The Irish type was not recovered from this site during the repeat sampling in June 1994; however, at that time of the year the nematodes may have been below the $10 \mathrm{~cm}$ soil depth to which it was sampled. In warm regions, Heterorhabditis tends to be found in the deeper soil layers during the summer, especially in soil which is more exposed to solar radiation (Glazer et al., 1996). The Irish type isolates from Denmark and
Hungary have not yet been fully characterised for biological traits; given the diversity amongst isolates of the type from Britain and Ireland (Hass, 1996) it would not be surprising if locally adapted ecotypes were detected amongst them.

A number of Heterorhabditis isolates collected in Hungary show rDNA ITS and rDNA NTS DNA restriction profiles identical to that of the American isolate of $\mathrm{H}$. bacteriophora, HP88, using key diagnostic restriction enzymes. However, the Hungarian isolates are not interfertile with HP88. HP88-compatible nematodes do occur in Europe, however, as evidenced by the cross-breeding success with the Darmstadt strain. The incompatibility between HP88 and the Hungarian HP88-like isolates is at the post-mating level, and results in either hybrid inviability or hybrid sterility depending on the direction of the cross. Embryos were formed in all of the crosses that were carried out. These embryos grew into apparently normal but sterile adults if the maternal partner for the cross was from either the HP88 or Darmstadt strain. Whether genetic or cytoplasmic maternal factors play an important role in the reproductive isolation between these isolates has not been determined.

The results of this survey provide further evidence of a geographic separation in Europe between the H. megidislike nematodes (the Irish and NWE types of Heterorhabditis), found predominantly in northern Europe, and the $H$. bacteriophora group found in southern and central Europe. However, the occurrence of the Irish group in Hungary (present study) and of H. megidis in Greece (Menti et al., 1997) clearly indicates that a division between a northern 'megidis' group and a southern $\mathrm{H}$. bacteriophora group is too simplistic.

The recovery rate of Heterorhabditis was much higher in this study, in which sites with sandy soils were specifically targeted for sampling, than in non-targeted surveys conducted in neighbouring areas of Europe. Thus, Heterorhabditis was recovered at one third of sites in Hungary, but was not recovered in the survey of Czechoslovakia (Mrácek, 1980). Similarly, the recovery rate of $\mathrm{He}$ terorhabditis at $38.5 \%$ of sites in Sjælland is considerably higher than in West-Flanders (Belgium) (5\% of sites) (Miduturi et al., 1996) or in the Netherlands (13\% of sites) (Hominick et al., 1995). The efficacy of targeted sampling in recovering strains of Heterorhabditis was previously demonstrated in Ireland and Britain: Griffin et al. (1994b) recovered Heterorhabditis from 4-45\% of sandy sites, while in general surveys, it either was not detected (Blackshaw, 1988; Boag et al., 1992; Gwynn \& Richard- 
son, 1996) or was present at only one site per survey (Hominick \& Briscoe, 1990; Griffin et al., 1991). The relatively high prevalence of Heterorhabditis in Sjælland and Estonia in the present study also contrasts with the apparent rarity of the genus across the Baltic sea in Sweden, Finland and Norway (Burman et al., 1986; Vänninen et al., 1989; Haukeland, 1993); but this may again reflect the relative amounts of sampling effort in the favoured habitat. Targeted sampling in Norway yielded a Heterorhabditis isolate from a sandy soil within $50 \mathrm{~m}$ of the sea (Haukeland Salinas, 1996).

The aim of our research was primarily the recovery of strains of Heterorhabditis. The targeting of sandy soil is considered a key strategic feature in this regard. Another factor which we consider may contribute to the relatively high prevalence of Heterorhabditis recorded in this and the study of Griffin et al. (1994b) is that each sample consisted of many ( $c a 40$ ) subsamples, a strategy designed to maximise the recovery of organisms such as Heterorhabditis which have a clumped distribution (Stuart \& Gaugler, 1994). Bednarek (1986) recommended that at least 50 (sub)samples should be collected to allow one to be convinced that entomopathogenic nematodes will be detected if present. Nevertheless, even where several samples (each of about 40 subsamples) were collected at a given site, we are not convinced that failure to detect $\mathrm{He}$ terorhabditis reflects its absence from that site; in Ireland, Heterorhabditis may sometimes be present at very low frequencies in the sandy coastal habitats to which it is restricted (Downes, 1995).

While Heterorhabditis was recovered from a higher proportion of sites in Kecskemét than Debrecen, higher proportions of bait insects were parasitised in the positive Debrecen samples, suggesting a higher nematode population density in these samples. Nematode population densities are affected by several factors. However, the Debrecen soils were notably less sandy than those in any of the other regions sampled in this study, and a number of studies (Ishibashi \& Kondo, 1987; Kung et al., 1990) suggest that IJ of entomopathogenic nematodes survive longer in heavier soils. They would also be expected to disperse less. Heavier soils may then have fewer, more concentrated populations while sands may have more numerous, dispersed populations.

Two species of Heterorhabditis were found to occur together at the same site twice in this study. Irish type Heterorhabditis occurred together with $H$. bacteriophora at a site in Hungary, and it occurred together with NWE type $H$. megidis at a Danish site. Reports of the co-occurrence of heterorhabditid species are rare; but Amarasinghe et $a l$. (1994) recovered $H$. indica and an unidentified heterorhabditid from a single sample in Sri Lanka. Coexistence may be facilitated by species having different foraging strategies (Koppenhöfer \& Kaya, 1996) or other differences of behaviour or life cycle. Little is known of the host preferences of European heterorhabditids; however, $H$. bacteriophora and the Irish type are not closely related (Smits et al., 1991; Adams et al., 1998) and show different biological characteristiscs (Griffin et al., 1994a; Hass, 1996). On the other hand, Irish type Heterorhabditis and NWE type $H$. megidis, which were found together at one site in Denmark, are closely related (Smits et al., 1991; Adams et al., 1998) and members of the two types are similar in several biological characteristics (Griffin et al., 1994a; Hass, 1996). It is unknown whether the two Heterorhabditis types parasitise the same host species where they occur together. Although not expected on theoretical grounds, Steinernemafeltiae and S. affinis were found parasitising the same species (and sometimes even the same individual larva) of bibionid fly in Denmark (Bovien, 1937; Poinar \& Lindhardt, 1971). However, there is some indication of association of Irish type Heterorhabditis with roses in Sjælland. Irish type was more likely than the NWE type to be found at sites with Rosaceae, and at the site where the two types occurred together, the Irish type was in a sample taken from shrub (including Rosaceae) dominated area. This perhaps indicates that in Denmark the Irish type is specialising on hosts associated with these plants or with their associated community. Such an association occurs, for example, between $H$. marelata and bush lupins in Bodega Bay, California (Strong et al., 1996).

The occurrence together of Irish type Heterorhabditis and of the NWE type of $H$. megidis presents an exciting opportunity to study how these closely related but distinct species avoid competitive displacement in Danish sand dunes.

\section{Acknowledgements}

We are grateful to the directorate of Kiskunsági National Park for permission to collect within the Park, and to Dr J. Kelemen and Mr F. Pál-Szabó for help in the planning and execution of the sampling in the Kecskemét region. This work was carried out with the financial assistance of the EU (ECLAIR contract AGRE 0002). 


\section{References}

Adams, B.J., Burnell, A.M. \& Powers, T.O. (1998). A phylogenetic analysis of the genus Heterorhabditis (Nemata: Rhabditidae) based on internal transcribed spacer I DNA sequence data. Journal of Nematology 30, 22-39.

Akhurst, R.J. \& BEDDING, R.A. (1986). Natural occurrence of insect pathogenic nematodes (Steinernematidae and Heterorhabditidae) in soil in Australia. Journal of the Australian Entomological Society 25, 241-244.

Akhurst, R.J. \& BRooks, W.M. (1984). The distribution of entomophilic nematodes (Heterorhabditidae and Steinernematidae) in North Carolina. Journal of Invertebrate Pathology 44, 140-145.

Amarasinghe, L.D., Hominick, W.M., Briscoe, B.R. \& REID, A.P. (1994). Occurrence and distribution of entomopathogenic nematodes in Sri Lanka. Journal of Helminthology 68, 277-286.

BEDNAREK, A. (1986). Estimation of the occurrence in soil of infective juveniles of entomogenous nematodes (Rhabditida: Steinernematidae, Heterorhabditidae). Revue de Nématologie 9, 414-416.

BLACKSHAW, R.P. (1988). A survey of insect parasitic nematodes in Northern Ireland. Annals of Applied Biology 113, 561-565.

BoAg, B., Neilson, R. \& Gordon, S.C. (1992). Distribution and prevalence of the entomopathogenic nematode Steinernema feltiae in Scotland. Annals of Applied Biology 121, 355360.

BoviEn, P. (1937). Some types of association between nematodes and insects. Videnskabelige Meddelelser fra Dansk naturhistorisk Forening 101, 1-144.

Burman, M., Abrahamson, K., Ascard, J., Sjöberg, A. \& ERIKSSON, B. (1986). Distribution of insect parasitic nematodes in Sweden. Proceedings, 4th International Colloquium of Invertebrate Pathology, Veldhoven, The Netherlands: 312 [Abstr.].

Deseö, K.V. \& Miller, L.A. (1985). Efficacy of entomogenous nematodes, Steinernema spp., against clearwing moths, Synanthedon spp., in north Italian apple ochards. Nematologica 31, 100-108.

DiX, I., Burnell, A.M., Griffin, C.T., Joyce, S.A., NuGent, M.J. \& Downes, M.J. (1992). The identification of biological species in the genus Heterorhabditis (Nematoda: Heterorhabditidae) by cross-breeding second generation amphimictic adults. Parasitology 104, 509-518.

Downes, M.J. (1995). Conceptual approaches to effects of interacting host size and density on genetic diversity in entomopathogenic nematode populations. In: Griffin, C.T., Gwynn, R.L. \& Masson, J.P. (Eds). Ecology and transmission strategies of entomopathogenic nematodes. Brussels, Belgium, European Commission, pp. 69-76.

Finnegan, M.M., Downes, M.J., O'Regan, M. \& GRIFFIN, C.T. (1999). Effect of salt and temperature stresses on survival and infectivity of Heterorhabditis spp. infective juveniles. Nematology 1, 69-78.

Glazer, I., Kozodoi, E., Salame, L. \& Nestel, D. (1996). Spatial and temporal occurrence of natural populations of Heterorhabditis spp. (Nematoda: Rhabditida) in a semiarid region. Biological Control 6, 130-136.

Grenier, E., Bonifassi, E., Abad, P. \& Laumond, C. (1996). Use of species-specific satellite DNAs as diagnostic probes in the identification of Steinernematidae and Heterorhabditidae entomopathogenic nematodes. Parasitology 113, 483-489.

Griffin, C. T., Finnegan, M.M. \& Downes, M.J. (1994a). Environmental tolerances and the dispersal of $\mathrm{He}$ terorhabditis: survival and infectivity of European Heterorhabditis following prolonged immersion in seawater. Fundamental and Applied Nematology 17, 415-421.

Griffin, C.T., Joyce, S.A., Dix, I., Burnell, A.M. \& Downes, M.J. (1994b). Characterisation of the entomopathogenic nematodes Heterorhabditis (Nematoda: Heterorhabditidae) from Ireland and Britain by molecular and cross-breeding techniques, and the occurrence of the genus in these islands. Fundamental and Applied Nematology 17, 245-253.

Griffin, C.T., Moore, J.F. \& Downes, M.J. (1991). Occurrence of insect-parasitic nematodes (Steinernematidae, Heterorhabditidae) in the Republic of Ireland. Nematologica 37, 92-100.

GWYNN, R.L \& RichaRdSON, P.N. (1996). Incidence of entomopathogenic nematodes in soil samples collected from Scotland, England and Wales. Fundamental and Applied Nematology 19, 427-431.

Hara, A.H., Gaugler, R., Kaya, H.K. \& Lebeck, L.M. (1991). Natural populations of entomopathogenic nematodes (Rhabditida: Heterorhabditidae, Steinernematidae) from the Hawaiian Islands. Environmental Entomology 20, 211-216.

HAss, B. (1996). Persistence of entomopathogenic nematodes of the genus Heterorhabditis Poinar, 1975 with emphasis on effects of natural ageing under starvation. Ph.D. Thesis, National University of Ireland, 179 p.

HAUKELAND, S. (1993). Entomopathogenic nematodes found in Norway. Norwegian Journal of Agricultural Science 7, 1727.

Haukeland Salinas, S. (1996). [Beneficial nematodes natural occurrence in Norway.] Gartneryrket 7, 13-17.

Hominick, W.M. \& BRiscoe, B.R. (1990). Occurrence of entomopathogenic nematodes (Rhabditida: Steinernematidae and Heterorhabditidae) in British soils. Parasitology 100, 295-302.

Hominick, W.M., Reid, A.P., \& Briscoe, B.R. (1995). Prevalence and habitat specificity of steinernematid and heterorhabditid nematodes isolated during soil surveys of the UK and the Netherlands. Journal of Helminthology 69, 1-6.

IshiBASHI, N. \& Kondo, E. (1987). Dynamics of the entomogenous nematode Steinernema feltiae applied to soil with 
and without nematicide treatment. Journal of Nematology 19 , 404-412.

Joyce, S.A., Burnell, A.M. \& Powers, T.O. (1994a). Characterization of Heterorhabditis isolates by PCR amplification of segments of mtDNA and rDNA genes. Journal of Nematology 26, 260-270.

Joyce, S.A., Griffin, C.T. \& Burnell, A.M. (1994b). The use of isoelectric focusing and polyacrylamide gel electrophoresis of soluble proteins in the taxonomy of the genus Heterorhabditis (Nematoda: Heterorhabditidae).Nematologica 40, 601-612.

Joyce, S.A., Reid, A., Driver, F. \& Curran, J. (1994c). Application of polymerase chain reaction (PCR) methods to the identification of entomopathogenic nematodes. In: Burnell, A.M., Ehlers, R.-U. \& Masson, J.P. (Eds). Genetics of entomopathogenic nematode-bacterium complexes. Brussels, Belgium, European Commission, pp. 41-48.

Koppenhöfer, A.M. \& KAYA, H.K. (1996). Coexistence of two steinernematid nematode species (Rhabditida: Steinernematidae) in the presence of two host species. Applied Soil Ecology 4, 221-230.

Kung, S.-P., Gaugler, R. \& Kaya, H.K. (1990). Soil type and entomopathogenic nematode persistence. Journal of Invertebrate Pathology 55, 401-406.

Menti, H., Wright, D.J. \& Perry, R.N. (1997). Desiccation survival of populations of the entomopathogenic nematodes Steinernemafeltiae and Heterorhabditismegidis from Greece and the UK. Journal of Helminthology 71, 41-46.

Miduturi, J.S., Moens, M., Hominick, W.M., Briscoe, B.R. \& REID, A.P. (1996). Naturally occurring entomopathogenic nematodes in the province of West-Flanders, Belgium. Journal of Helminthology 70, 319-327.
MrÁČEK, Z. (1980). The use of “Galleria traps" for obtaining nematode parasites of insects in Czechoslovakia (Lepidoptera: Nematoda, Steinernematidae). Acta Entomologica Bohemoslovaca 77, 378-382.

MrÁČEK, Z. \& JENSER, G. (1988). First report of entomogenous nematodes of the families Steinernematidae and Heterorhabditidae from Hungary. Acta Phytopathologica et Entomologica Hungarica 23, 153-156.

PoinAR, G.O., JR (1990). Biology and taxonomy of Steinernematidae and Heterorhabditidae. In: Kaya, H.K. \& Gaugler, R. (Eds). Entomopathogenic nematodes in biological control. Boca Raton, FL, USA, CRC Press, pp. 23-61.

PoinAR, G.O., JR \& LindhaRdT, K. (1971). The re-isolation of Neoaplectana bibionis Bovien (Nematoda) from Danish bibionids (Diptera) and their possible use as biological control agents. Acta Entomologica Scandinavica 2, 301-303.

Smits, P.H., Groenen, J.T.M. \& de RaAy, G. (1991). Characterization of Heterorhabditis isolates using DNA restriction length polymorphism. Revue de Nématologie 14, 445-453.

Strong, D. R., Kaya, H.K., Whipple, A.V., Child, A.L., Kraig, S., Bondonne, M., Dyer, K. \& Maron, J.L. (1996). Entomopathogenic nematodes: natural enemies of root-feeding caterpillars on bush lupin. Oecologia 108, 3945.

Stuart, R.J. \& Gaugler, R. (1994). Patchiness in populations of entomopathogenic nematodes. Journal of Invertebrate Pathology 64, 39-45.

V nninen, I., Husberg, G.B. \& Hokkanen, H. (1989). Occurrence of entomopathogenic fungi and entomoparasitic nematodes in cultivated soil in Finland. Acta Entomologica Fennica 53, 65-71. 